\title{
DISASTER MEDICINE and
}

\section{PUBLIC HEALTH PREPAREDNESS}

An Official Publication of the Society for Disaster Medicine and Public Health, Inc

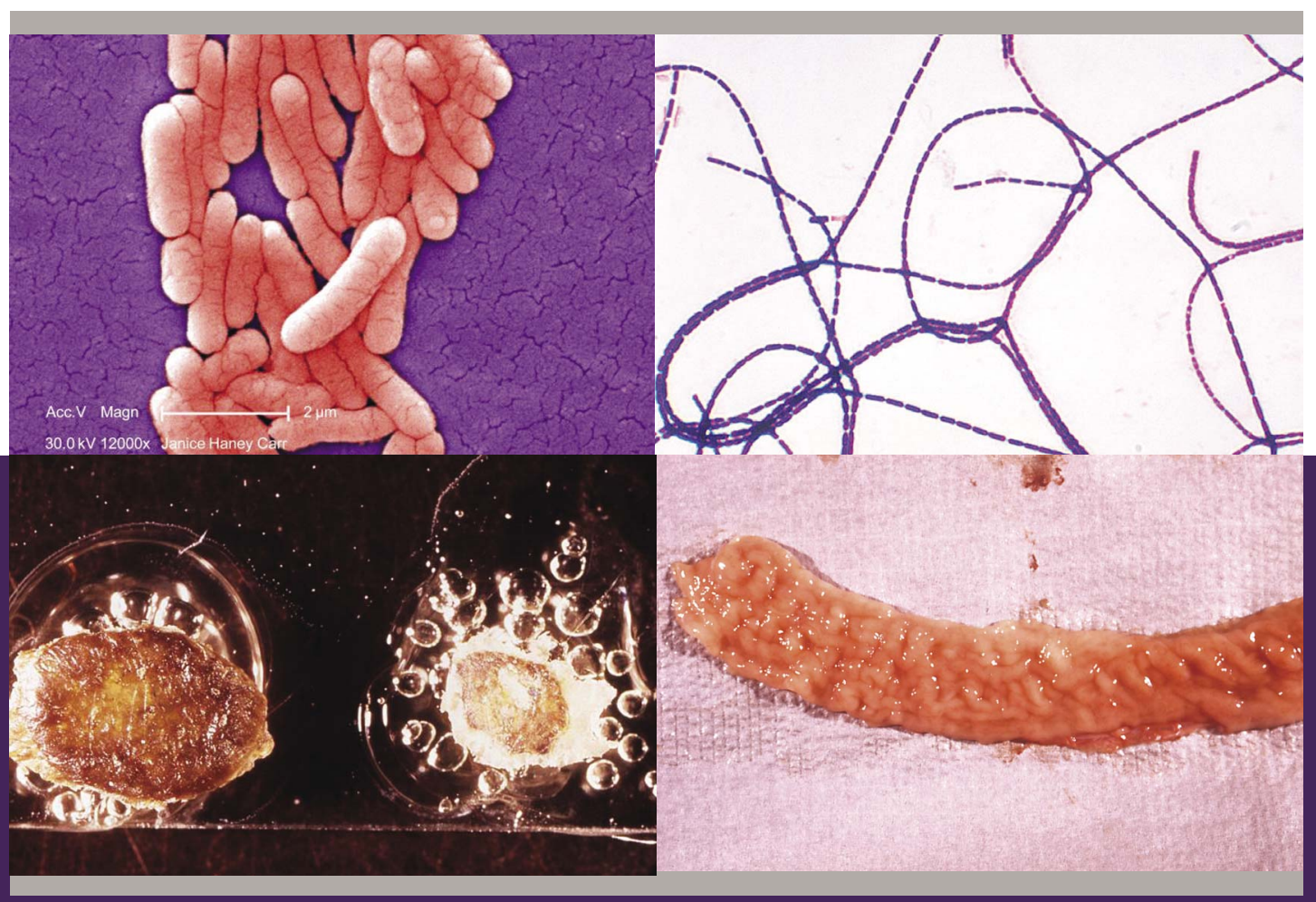

IN THIS ISSUE:

In a Japanese operating room during a severe earthquake Suggestions for better taxonomies and terminologies Surge in Ventilator Use During Influenza Outbreaks Hospital Safety during Disaster

Knowledge and Confidence of Israeli Healthcare workers During the H1N1 Pandemic 

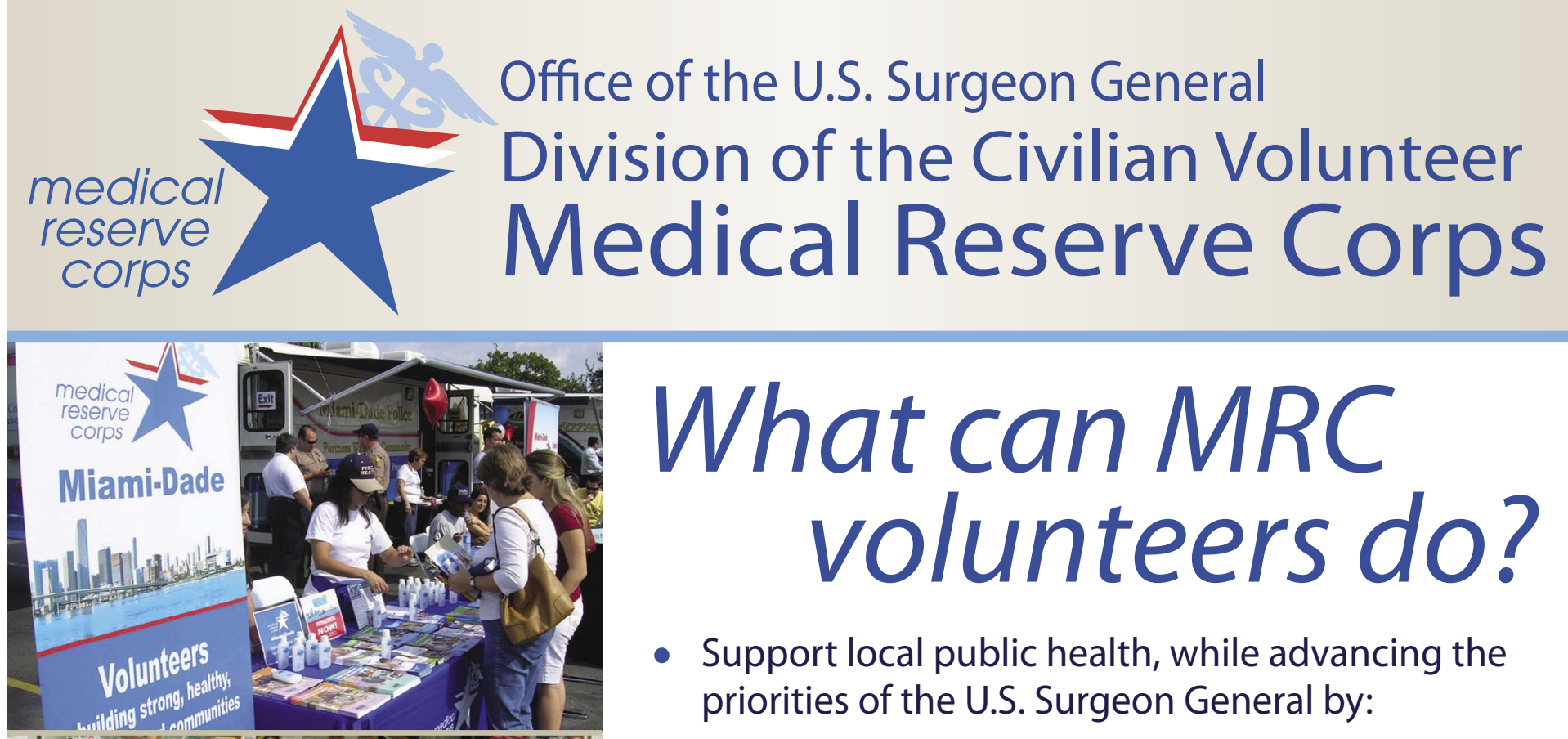

What can MRC

\section{volunteers do?}

- Support local public health, while advancing the priorities of the U.S. Surgeon General by:

$\checkmark$ Promoting disease prevention

$\checkmark$ Improving health literacy

$\checkmark$ Eliminating health disparities

$\checkmark$ Enhancing public health preparedness

- Assist local hospitals and health departments with surge personnel needs

- Participate in mass prophylaxis and vaccination exercises and community disaster drills

- Train with local emergency response partners

- And much more...

Connect with your local MRC unit today! www.MedicalReserveCorps.gov

The Tower Building

1101 Wootton Parkway, Suite 200

Rockville, MD 20852

240.453.2839 • MRCcontact@hhs.gov

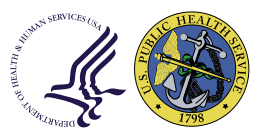

Volunteers Building Strong, Healthy, and Prepared Communities 


\section{Disaster Medicine and Public Health Preparedness}

Editor-in-Chief
James J. James, MD, DrPH, MHA

Chief Executive Officer,

Society for Disaster Medicine and

Public Health, Inc., USA
Deputy Editor

David Markenson, MD, MBA

Chief Medical Officer

Sky Ridge Medical Center

Director, Center for Disaster Medicine

New York Medical College

\section{Associate Editors}

Elizabeth Ablah, PhD, MPH

Associate Professor,

University of Kansas-Wichita,

School of Medicine

Daniel J. Barnett, MD, MPH

Assistant Professor,

Department of Environmental

Health Sciences, Johns Hopkins

Bloomberg School of Public Health

Laura J. Cavanaugh, MD, FAAP

Pediatrician, Private Practice, USA

Jennifer L. Chan, MD, MPH

Assistant Professor, Department

of Emergency Medicine,

Northwestern Feinberg School of

Medicine
Edbert B. Hsu, MD, MPH

Director of Training,

Johns Hopkins Office of Critical Event

Preparedness and Response

Stephanie Kayden, MD, MPH

Director, International Emergency Medicine Fellowship, Brigham and Women's Hospital

Frederick C. Nucifora Jr., DO, PhD, MHS

Department of Psychiatry and

Behavioral Science, Johns Hopkins

University School of Medicine

Michael J. Reilly, DrPH, MPH,

NREMT-P, CEM

Center for Disaster Medicine, New York Medical College

\section{Managing Editor}

Alice O'Donnell

HJF, National Center for Disaster Medicine and Public Health

Editorial support provided by the National Center for Disaster Medicine and Public Health

\section{Editorial Board}

\section{John Armstrong, MD, FACS}

Associate Professor of Surgery,

USF Health, University of South Florida

Frederick M. Burkle Jr., MD, MPH, DTM, FAAP, FACEP

Senior Fellow, Harvard Humanitarian Initiative, Harvard School of Public Health

\section{Cham E. Dallas, PhD}

Director, Institute for Health Management in Mass Destruction Defense, University of Georgia \& Medical College of Georgia

\section{Linda C. Degutis, DrPH, MSN}

Director, National Center for Injury

Prevention and Control, Centers for Disease Control and Prevention

Lewis R. Goldfrank, MD

Herbert W. Adams Professor and Chair, Department of Emergency Medicine,

New York University

Medical Director, New York City Poison Center

John L. Hick, MD

Associate Professor of Emergency

Medicine, Hennepin County Medical

Center, University of Minnesota

James G. Hodge, Jr., JD, LLM

Lincoln Professor of Health Law and Ethics Director, Public Helath Law and Policy

Program, Sandra Day O'Connor College of Law, Arizona State University
Gabor Kelen, MD, FRCP(C), FACEP

Professor and Chair, Department of Emergency Medicine, Johns Hopkins University

Thomas D. Kirsch, MD, MPH, FACEP

Associate Professor, Director of the Center for Refugee and Disaster

Response. The Johns Hopkins

School of Medicine/Bloomberg

School of Public Health

William Lanier, MD

Professor of Anesthesiology, Mayo Clinic

Yasuhiro Otomo, MD, PhD

Director, Trauma and Acute Critical

Care Medical Center

Professor and Chairman,

Tokyo Medical and Dental University

Hospital of Medicine, Japan

Betty Pfefferbaum, MD, JD

Chairman, Department of Psychiatry and Behavioral Sciences, University of Oklahoma Health Sciences Center

Irwin Redlener, MD

Director, National Center for Disaster Preparedness, Columbia University

Charles L. Rice, MD

President, Uniformed Services University of the Health Sciences

\section{W. Craig Vanderwagen, MD}

RADM, US Public Health Service, retired Senior Partner, Martin, Blanck and Associates

\section{Statistical Editors}

Guohua Li, MD, DrPH

M. Finster Chair in Anesthesiology and Epidemiology, Columbia

University College of Physicians and Surgeons

Michael A. Stoto, PhD

Professor, Health Services Administration and Population Health, Georgetown University School of Nursing and Health Studies

\section{Chair of Global Committee}

Raymond E. Swienton, MD, FACEP

Co-director of EMS, Disaster Medicine and Homeland Security Section, University of

Texas Southwestern

\section{Associate Board}

Erik Auf der Heide, MD, MPH, FACEP

Agency for Toxic Substances

and Disease Registry,

US Department of Health and

Human Services
Joseph A. Barbera, MD

Co-director, Institute for Crisi, Disaster, and Risk Mangagement, The George Washington University
Donna F. Barbisch, DrHA, MPH

Director, Institute for Global and Regional Readiness 


\section{Steven M. Becker, PhD}

Professor, College of Health Sciences Old Dominion University

Georges Benjamin, MD, FACP

Executive Director, American Public Health Association

John Brownstein, PhD

Associate Professor, Clinical and Public Health Informatics, Boston Children's Hospital

Arthur Cooper, MD, MS, FACS, FAAP, FCCM

Director of Trauma \& Pediatric Surgical Services, Harlem Hospital Center

Asha Devereaux, MD, MPH

Chair, American College of Chest

Physicians Disaster Response Network

\section{Edward Eitzen, MD, MPH}

Senior Partner, Biodefense and Public Health Programs, Martin, Blanck and Associates

\section{Mikael Eliasson, MD, PhD}

Strategic Marketing Leader, General Medicine, GE Healthcare

\section{Joshua Epstein, PhD}

Director, Center on Social and Economic Dynamics, The Brookings Institution

\section{J. Christopher Farmer, MD, FCCM}

Associate Dean, Critical Care Medicine, Mayo Clinic College of Medicine

\section{Richard Garfield, RN, DrPH}

Henrik H. Bendixen Professor of Clinical International Nursing, Columbia University

Jeffrey Hammond, MD, MPH

Clinical Professor of Surgery, Robert Wood Johnson Medical School

\section{Global Committee}

Michael Christian, MD, FRCP(C)

Department of Medicine, University of

Toronto, Canada

Herman Delooz, MD, PhD, FCCM, FCEM (dist)

Research Group on Disaster Medicine, Free University of Brussels

\section{D.A. Henderson, MD, MPH}

Center for Biosecurity, University of Pittsburgh Medical Center

David Joyner, MD

Vice Chairman/CMO, Salus Healthcare International

\section{David Lakey, MD}

Commissioner, Texas Department of State Health Services

\section{E. Brooke Lerner, PhD}

Department of Emergency Medicine, Medical College of Wisconsin

\section{Jonathan Links, PhD}

Director, Center for Public Health Preparedness, Johns Hopkins Bloomberg School of Public Health

Craig H. Llewellyn, MD, MPH, MSTMH, FACPM

Emeritus Professor of Military Medicine, Emergency Medicine, Preventative Medicine \& Surgery, Uniformed Services University School of Medicine

Darrell E. Lovins, DO, MPH, FACOFP Associate Dean, Clinical Sciences, William Carey University

\section{Anthony Macintyre, MD}

Visiting Associate Professor, Institute for Crisis, Disaster, and Risk Management, The George Washington University

\section{John Mutter, PhD}

Professor of International and Public Affairs, The Earth Institute at Columbia University

\section{Kobi Peleg, PhD, MPH}

Director, Israel National Center for Trauma and Emergency Medicine
Cheryl Peterson, RN, MSN

Senior Policy Fellow, American Nurses Association

\section{Steven J. Phillips, MD}

Director Specialized Information Services, Associate Director, National Library of Medicine, US Department of Health and Human Services

\section{Michael J. Reilly, DrPH, MPH}

Director. Center for Disaster Medicine Institute of Public Health

\section{Louis Rowitz, PhD}

Professor, Community Health Sciences, School of Public Health. University of Illinois at Chicago

\section{Joseph Scanlon}

Professor Emeritus and Director, Emergency Communications and Research Unit, Carleton University

\section{R. Tom Sizemore III, MD}

Principal Deputy Director, Office of Preparedness and Emergency Operations, US Department of Health and Human Services

\section{Robert Ursano, MD}

Professor/Chair, Department of Psychiatry, Uniformed Services University of the Health Sciences

\section{Jeb Weisman, PhD}

Director of Strategic Technologies, National Center for Disaster Preparedness, Columbia University

\section{Kevin Yeskey, MD}

Senior Advisor for Emergency Public Health, $M D B$, Inc.
Natalia Gudzenko, MD

Laboratory for Cancer Epidemiology, Research Center for Radiation Medicine, Ukraine

Keqin Rao, MD, MPH

Director, National Center for Health Statistics and Information, Ministry of Health, China

\section{Alessandra Rossodivita, MD EMDM}

San Raffaele Hospital Scientific Foundation, Milan, Italy

Nobhojit Roy, MD, MPH

Bhabha Atomic Research Center Hospital, Mumbai, India 


\section{Disaster Medicine and Public Health Preparedness}

April 2014

Vol 8/No 2

On the Cover

111 Changing the Taxonomy in Public Health and Medicine Marvin L. Birnbaum

Commentary

112 The Language of Disease Outbreaks, Disasters, and Public Health Emergencies: The Role of the US National Library of Medicine Steven J. Phillips, Stacey J. Arnesen, and Cynthia B. Love

Editorial

114 Disaster Medicine and Public Health Preparedness: A Discipline for All Health Professionals-Redux James J. James

Letter to the Editor

117 Possible Anisakiasis Associated with Fishery Resumption Yoshitaka Nishikawa, Masaharu Tsubokura, Shigeaki Kato, and Yasutoshi Saito

From the Field

119 Rebuilding Emergency Care After Hurricane Sandy

David C. Lee, Silas W. Smith, Christopher M. McStay, lan Portelli, Lewis R. Goldfrank, Gregg Husk, and Nirav R. Shah

Original Research

123 The Operating Room During a Severe Earthquake: Lessons From the 2011 Great East Japan Earthquake

Yasuyuki Suzuki, Ikuo Fukuda, and Shigeyuki Nakaji

130 Scintigraphic Evaluation of Decontamination Lotion for Removal of Radioactive Contamination From Skin

Sudha Rana, Mita Dutta, Navneet Sharma, Rajeev Goel, Abdul Wadood Khan, Sabna Kotta, Javed Ali, Shahid Husain Ansari, Sarwat Sultana, and Rakesh Kumar Sharma

136 Surge in Hospitalizations Associated With Mechanical Ventilator Use During Influenza Outbreaks James C. King Jr, Adebola Ajao, Richard Lichenstein, and Laurence S. Magder

143 An Analysis of Mass Casualty Incidents in the Setting of Mass Gatherings and Special Events

Sheila A. Turris, Adam Lund, and Ronald R. Bowles 
150 Health Care Workers' Knowledge and Confidence in Personal Protective Equipment During the H1N1 Pandemic in Israel

Dagan Schwartz, Stav Shapira, and Yaron Bar-Dayan

158 Risk Communication Recommendations and Implementation During Emerging Infectious Diseases: A Case Study of the 2009 H1N1 Influenza Pandemic

Anat Gesser-Edelsburg, Emilio Mordini, James J. James, Donato Greco, and Manfred S. Green

Brief Report

170 Preparations for Severe Winter Conditions by Emergency Health Personnel in Turkey

Cüneyt Çalışkan, Aysun Algan, Hüseyin Koçak, Burcu Küçük Biçer, Meltem Şengelen, and Banu Cakir

\section{Concepts in Disaster Medicine}

174 Disaster Trauma: Federal Resources that Help Communities on Their Road to Recovery

Stephanie S. Felder, Jamie Seligman, Cicely K. Burrows-McElwain, Maryann E. Robinson, and Erik Hierholzer

179 Nonstructural Safety of Hospitals for Disasters: A Comparison Between Two Capital Cities

Ahmadreza Djalali, Ali Ardalan, Gunnar Ohlen, Pier Luigi Ingrassia, Francesco Della Corte, Maaret Castren, and Lisa Kurland

List of Reviewers

\section{Thank You, Reviewers!}

\section{CONTACT INFORMATION}

\section{Editorial Office}

NCDMPH

11300 Rockville Pike, Suite 1000

Rockville, MD 20852

P: $240-833-4429$

E: dmphpjournal@gmail.com

Edited from the Offices of the National Center for Disaster Medicine and Public Health (NCDMPH) located at the Uniformed Services University of the Health Sciences (USUHS) under a cooperative enterprise agreement between USUHS and The Society for Disaster Medicine and Public Health. The views expressed in each article are those of the author and do not necessarily reflect the official policy or position of NCDMPH, USUHS, the Department of Defense, or the United States Government.

Manuscript Submission and Instructions for Authors

May be found online at http://manuscripts.dmphp.org

\section{DMPHP Reprints \& Permissions}

Article Reprints/E-prints Inquiry

For use by commercial entities or educational institutions:

special_sales@cambridge.org

\section{Permissions Inquiry}

For rights and permissions inquiries, please visit www.cambridge.org/about-us/ rights-permissions

\section{Advertising}

For details about advertising rates and opportunities in Disaster Medicine and Public Health Preparedness, or to request a media pack, please contact us at USAdSales@ cambridge.org.

\section{Subscription Rates and Service}

\section{Subscription Information}

Disaster Medicine and Public Health Preparedness (ISSN: 1935-7893; EISSN:

1938-744X) is published bi-monthly by Cambridge University Press, 32 Avenue of the Americas, New York, New York 10013. Copyright (C) 2014 by the Society for Disaster Medicine and Public Health, Inc.

\section{Annual Subscription Rates}

Annual institutional print and electronic subscription rates: US \$545.00 in the USA Canada and Mexico; UK £341.00 + VAT elsewhere. Institutional electronic rates only: US $\$ 418.00$ in the USA, Canada and Mexico; UK $£ 261$ + VAT elsewhere. Prices include surface postage and insurance.

Information on Disaster Medicine and Public Health Preparedness and all other Cambridge journals is available at http://www.cambridge.org/. Full text for this journal may be found at http:// journals.cambridge.org/.

When citing this journal, please abbreviate as Disaster Med Public Health Preparedness.

Indexed in MEDLINE.

Disaster Medicine and Public Health Preparedness participates in the Health InterNetwork Access to Research Institute Initiative (HINARI), which provides free or very-low-cost online access to major journals in biomedical and related social sciences to local, nonprofit institutions in developing countries. Please visit www.who.int/hinari for more information.

Copyright $\odot 2014$ Society for Disaster Medicine and Public Health, Inc.

All rights reserved. No part of this publication may be reproduced, in any form or by any means, electronic photocopying or otherwise, without permission in writing from Cambridge University Press, except when permission is obtained through a bona fide copyright clearinghouse, such as the Copyright Clearance Center (USA) or the Copyright Licensing Agency (UK). For further information please visit http://us.cambridge.org/information/rights/ or http://www.cambridge.org/uk/ information/rights/.

Periodicals postage paid at New York, NY, and additional mailing offices. Return Postage Guaranteed. Postmaster: Send address changes in the USA and Canada to: Disaster Medicine and Public Health Preparedness, Cambridge University Press, Journals Fulfillment Dept., 100 Brook Hill Drive, West Nyack, NY 10994-2133. 